\title{
The development of an open-access database for human transcriptional regulation interactions
}

\author{
Luiz Augusto Bovolenta*, Marcio Luis Acencio, Ney Lemke \\ From Seventh International Society for Computational Biology (ISCB) Student Council Symposium 2011 \\ Vienna, Austria. 15 July 2011
}

\section{Background}

The modeling of interactions among transcription factors (TFs) and their respective target genes (TGs) into transcriptional regulatory networks is important for the complete understanding of regulation of biological processes. In the case of human TF-TG interactions, there is no database at present that explicitly provides such information even though many databases containing human TF-TG interaction data have been available, such as TRANSFAC [1] and TRED [2]. In an effort to provide researchers with a repository of TF-TG interactions from which such interactions can be directly extracted, we present here the human transcriptional regulation interactions database (HTRIdb), an openaccess database of experimentally validated interactions among human TFs and their respective TGs.

\section{Materials and methods}

The HTRIdb is implemented as a relational database PostgreSQL that is connected to a web interface via the JBOSS AS application server that dynamically generates user-friendly HTML front-end queries using the Apache Tomcat web server. For the visualization of TF-TG interactions, we embedded in the HTRIdb the Cytoscape Web.

\section{Results}

The HTRIdb offers several mechanisms of data query and extraction, such as download in spreadsheet or text format and the visualization of TF-TG interactions. There is an update mechanism that allows scientists to send new data. The HTRIdb currently holds a collection

\footnotetext{
* Correspondence: labovolenta@gmail.com Department of Physics and Biophysics, Instituto de Biociências de Botucatu, Unesp -Univ Estadual Paulista, Botucatu -SP, Brazil
}

of 2,114 unique transcriptional regulation interactions among 163 TFs and 1,034 TGs.

\section{Conclusion}

HTRIdb is a powerful user-friendly tool from which human TF-TG interactions can be easily extracted.

\section{Acknowledgements}

We would like to thank The State of São Paulo Research Foundation (FAPESP) (grants 2009/10382-2 and 2010/20684-3) and CNPQ for the financial support.

Published: 21 November 2011

\section{References}

1. Matys V, Kel-Margoulis OV, Fricke E, Liebich I, Land S, Barre-Dirrie A, Reuter I, Chekmenev D, Krull M, Hornischer K, et al: TRANSFAC and its module TRANSCompel: transcriptional gene regulation in eukaryotes. Nucleic Acids Res 2006, 34(Database):D108-110.

2. Jiang C, Xuan Z, Zhao F, Zhang MQ: TRED: a transcriptional regulatory element database, new entries and other development. Nucleic Acids Res 2007, 35(Database):D137-140.

doi:10.1186/1471-2105-12-S11-A10

Cite this article as: Bovolenta et al:: The development of an open-access database for human transcriptional regulation interactions. $B M C$

Bioinformatics 2011 12(Suppl 11):A10.

Submit your next manuscript to BioMed Central and take full advantage of:

- Convenient online submission

- Thorough peer review

- No space constraints or color figure charges

- Immediate publication on acceptance

- Inclusion in PubMed, CAS, Scopus and Google Scholar

- Research which is freely available for redistribution

\section{Biomed Central}

